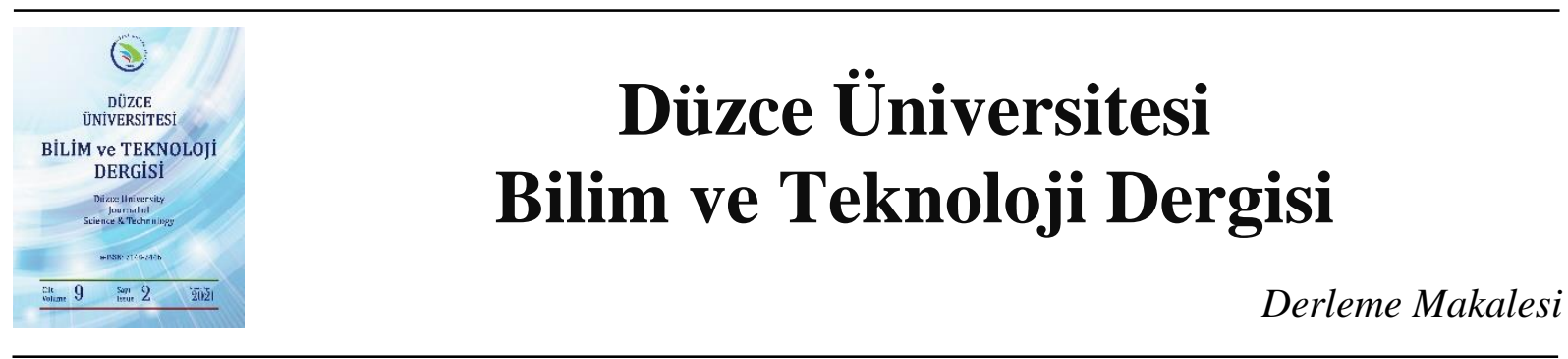

\section{Yenilenebilir Enerji Kaynaklarından Üretilen Elektrik Enerjisi Teşvik Yöntemlerinin İncelenmesi}

\author{
Uğur YÜCEL ${ }^{\mathrm{a}, *}$, (D) Engin ÖZDEMIR ${ }^{\mathrm{b}}$, (D) Murat AYAZ ${ }^{\mathrm{c}}$ \\ ${ }^{a}$ Mekatronik Programı, Hereke Asım Kocabıyı MYO, Kocaeli Üniversitesi, Kocaeli, TÜRKIYE \\ ${ }^{b}$ Enerji Sistemleri Mühendisliği, Teknoloji Fakültesi, Kocaeli Üniversitesi, Kocaeli, TÜRKIYYE \\ ${ }^{c}$ Elektrik ve Enerji Bölümü, Uzunçiftlik Nuh Çimento MYO, Kocaeli Üniversitesi, Kocaeli, TÜRKIYYE \\ * Sorumlu yazartn e-posta adresi: uyucel@kocaeli.edu.tr
}

DOI: 10.29130/dubited.774963

\begin{abstract}
ÖZET
Enerji ihtiyacımızı karşılarken yenilenebilir enerji kaynaklarından faydalanmak, çevresel sorunların azalmasını ve enerji üretimi için kullanılan kaynakların gelecek nesillere aktarılmasına imkân sağlamaktadır. Toplumların çevresel sorunlara ilgisinin artması, devletlerin enerji politikalarının şekillenmesine katkı sağlamış ve enerji verimliliği ile beraber yenilenebilir enerji kaynakları kullanılarak enerji üretimi konusunda yatırımlar hız kazanmıştır. Yenilenebilir enerji kaynakları kullanılarak elde edilen temiz enerjinin maliyetleri her ne kadar azalmıșsa da fosil yakıtlarla karşılaştırıldığında hala pahalı bir teknolojidir. Maliyet yüksekliği dönüşüm hızını düşüren bir etken olarak karşımıza çıkmaktadır. Bazı yenilenebilir enerji teknolojilerinin düşen maliyetleri fosil yakitlarla enerji üretim maliyetlerine çok yakın olsalar da hala birçok teknoloji rekabet edebilecek seviyede değildir. Birleşmiş Milletler ve Avrupa Birliği gibi Uluslararası kurumlarda, üye devletlerin ortak kararları ile fosil yakıtların düşük maliyetlerine karșı, yenilenebilir enerji üretim teknolojilerinin teșvik edilmesi kararları alınmıș ve belli hedefler konulmuştur. Temiz enerji üretimi için ihtiyaç olan sermayenin salt devletler tarafindan karşılanması yatırım hızını düşüren bir etken olarak karşımıza çıkmaktadır. Yönetimler temiz enerjiye yatırım yapmak isteyen kişi ve kuruluşlara teşvikler sağlayarak enerji dönüşümünün mali yükünü paylaşma yöntemini benimsemiștir. Devletler coğrafi koşulları, ekonomik ve teknolojik altyapılarına bağlı olarak enerji üretiminde yenilenebilir enerji kaynaklarına geçiş için farklı politikalar geliştirmektedir. Bu çalışmada farklı ülkelerde ve Türkiye'de yenilenebilir enerji kaynaklarının genel durumu ve bu kaynaklardan elektrik enerjisi üretimi için verilen teşvik yöntemleri incelenmektedir.
\end{abstract}

Anahtar Kelimeler: Yenilenebilir Enerji, Enerji Teşvikleri, Yenilenebilir Enerji Kaynakları

\section{Investigation of Incentive Methods for Electricity Produced from Renewable Energy Sources}

\begin{abstract}
Utilizing renewable energy resources to meet energy needs allows the reduction of environmental problems and the transfer of resources used for energy generation to future generations. The increasing interest of societies in environmental problems has contributed to form the energy policies of the states and investments in energy production by using renewable energy resources have accelerated. Although the costs of clean energy obtained from the renewable energy sources have decreased, it is still an expensive technology compared to fossil fuels. High cost is a factor that reduces the transformation rate. Although the decreasing costs of some renewable energy technologies are very close to the cost of generating energy from fossil fuels, many renewable energy technologies are still not at a competitive level. In the international institutions such as the United Nations and the European
\end{abstract}


Union, decisions have been taken to encourage renewable energy generation technologies against the lower cost fossil fuel sources and certain targets have been set. The fact that the capital required to produce clean energy is met only by the states is a factor that reduces the investment rate. The administrations have adopted the method of sharing the financial burden of the energy transformation by providing incentives to individuals and organizations that want to invest in clean energy. States develop different policies for transition to renewable energy sources in energy production, depending on their geographical conditions, economic and technological infrastructure. In this study, the overall situation of renewable energy sources and incentives for electric energy production from these sources in different countries and in Turkey, has been discussed.

Keywords: Renewable Energy, Energy Incentives, Energy Sources

\section{GIRIS}

Ana enerji kaynăgımız olan fosil yakıt kaynakları yüksek bir hızla tükenmekte ve bu yakıtlar kullanılarak enerji üretimi yapılması çevresel sorunlar oluşmasına sebep olmaktadır [1]. Fosil yakıt kullanmanın telafi edilemeyecek çevresel zararlara yol açması, yenilenebilir enerji kaynaklarının kullanılmasını zorunlu hale getirmiştir [2]. Fosil yakıtların oluşturduğu çevre kirliliği, küresel ısınma ve iklim değişikliği etkilerine karşı, 1997 yılında Birleşmiş Milletler Çerçeve Sözleşmesi kapsamında 192 ülke Kyoto Protokolü imzalanmıştır [3]. Alınan kararda ülkeler sera gazı salınımını \%80 oranında azaltmayı taahhüt etmişlerdir [4,5]. Avrupa Birliği Parlamentosu, Kyoto protokolünün hayata geçirilmesi amacı ile yenilenebilir enerji kaynaklarının kullanımına yönelik, 27 Eylül 2001 tarih ve 2001/77 / EC sayılı Avrupa Parlamentosu Konsey Direktifini yayınlamıştır [6,7]. Avrupa Parlamentosu 31 Ocak 2008 tarihinde onayladığ 1 kararla, 2020 yılına kadar yenilenebilir enerji kaynaklarından faydalanılarak üretilen enerjin oranını \%20'ye çıkarılmasına karar vermiştir [8]. 2019 yılında dünya üzerinde üretilen elektrik enerjisi bir önceki yıla göre \%1,5 artışla 27.004,7 TWh olarak gerçekleşmiştir. Bu enerjinin, \%36,4'ü kömürden, \%26'sı yenilenebilir enerji kaynaklarından, \%23,3'ü doğalgazdan, $\% 9,3$ 'ü nükleer kaynaklardan ve \%5'i diğer kaynaklardan elde edilmiştir. Yenilenebilir enerji kaynaklarının oluşturduğu \%26' lık dilimin, \% 15,6'lık kısmı hidroelektrik santraller ve \%10,4'lük kısmı ise rüzgar, güneş, biyokütle gibi gelişmekte olan diğer kaynaklardan elde edilen elektrik enerjini temsil etmektedir [9]. Mevcut durumda yenilenebilir enerji kaynakları elektrik enerjisi içinde ciddi bir paya sahip olmakla beraber, birincil kaynak durumuna gelmesi zaman alacaktır.

2020 yılının ilk yarısında AB'de hane halkı elektrik fiyatları, Almanya'da 0,3043 $€ / \mathrm{kWh}$ ile en yüksek, $0,0997 € / \mathrm{kWh}$ ile Bulgaristan'da en düşük değere sahiptir. Bölge ülkesi Türkiye'de ise hane halk1 elektrik fiyatı $0,0995 € / \mathrm{kWh}$ 'tir. Avrupa bölgesinde en düşük hane halkı fiyatı 0,0466 €/kWh ile Ukrayna'dadır. 2020 yılı ilk yarısı Avrupa Bölgesi hane halkı tüketicileri elektrik fiyatları Şekil 1'de görülmektedir [10].

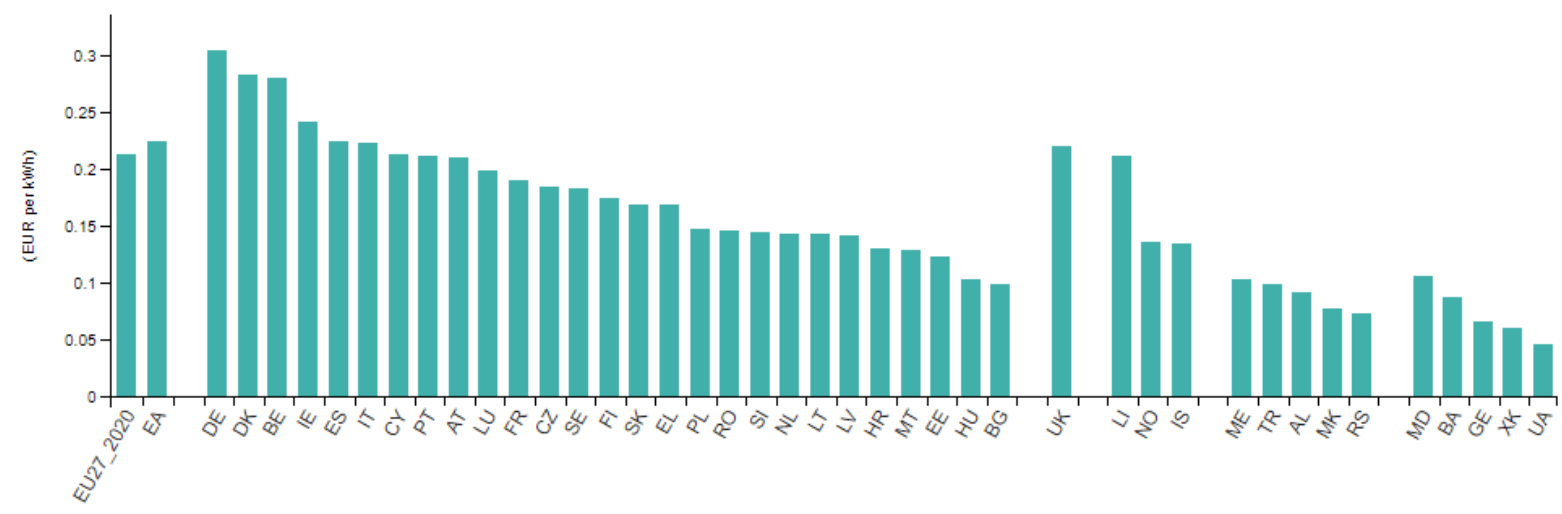

Şekil 1. 2020 yılı ilk yarısı Avrupa Bölgesi hane halkı tüketicileri için vergiler dahil elektrik fiyatları 
Yenilenebilir enerji teknolojilerinin etkileri temelde ekonomik düzeyde incelenmektedir. Mevcut konvansiyonel enerji sistemlerinin, yenilenebilir enerjiye dönüştürülmesi yeni bir ekonomik sektörün oluşmasını sağlamaktadır. Yatırım kararları ve yenilenebilir enerji teknolojilerinin sürdürülebilirliği, ekonomiyi kademeli olarak dönüştürmektedir. Kullanılmakta olan enerji tedarik modellerinin ekonomik büyümeye olan katkısının yerini, çevreyi ön planda tutan bir ekonomi almaktadır. Yeni iş tanımları ve kaynakların oluşması ekonomik ivmelenmeyi desteklemektedir $[11,12]$.

Dünya üzerinde yenilenebilir enerji kaynaklarının, toplam enerji kaynakları içindeki oranı sürekli artmaktadır. Yenilenebilir enerji teknolojilerinin hükümetler ve düzenleyici kurumlar tarafindan karma enerji grubuna girmesini teşvik etmek amacı ile çeşitli politik kararlar alınmakta ve destek mekanizmaları geliştirilmektedir [13]. Martin ve Arkadaşları Almanya, Avusturya ve İsviçre'de Yenilenebilir Enerji yatırımı yapan firmaların, yatırım gerekçelerini incelemiştir. Yatırımlar Almanya'da uygulanan vergi avantajlarının, İsviçre'de talebe bağlı faktörlerin ve Avusturya'da kamu sübvansiyonlarının yatırımcıyı yönlendirdiği tespit edilmiştir [14,15].

Coğrafi koşullar yenilenebilir enerji kaynakları (YEK) olarak kabul edilen rüzgâr, güneş, biyokütle, jeotermal, hidro enerji ve okyanus enerjilerinin kullanımında belirleyici unsurdur $[16,17,18]$. Yenilenebilir enerji kaynaklarını kullanmak, konvansiyonel kaynaklar olarak bildiğimiz fosil yakıtlar yönünden kısıtlı imkanlara sahip olan ülkelerin enerji bakımından dışa bağımlılıklarının azalmasını sağlar [19].

Yenilenebilir enerji teknolojilerinin ekonomik büyüme ve gelişme, sürdürülebilir "yeşil" büyüme, istihdamın ve yeni iş firsatlarının oluşması, yerel ekonomilerin geliştirilmesi, yeni anlayışların gelişmesi, teknolojik gelişim, ithalatın azalması, ticaret dengesinin iyileştirilmesi, kırsal alanlarda elektrik üretim kapasitesinin artırılması, imalat sanayinin ve diğer ilgili sanayilerin gelişimi, üretimin geliştirilmesi olarak özetlenebilir. Negatif ekonomik etkileri; büyük finansal teşviklere ihtiyaç duyması, enerji üretim maliyetinin yüksek olması, biyoyakıt üretimi için daha fazla gıda kullanılmasının gıda fiyatlarında artışa sebep olması, doğal özellikleri nedeniyle, yenilenebilir kaynakların coğrafi koşullara bağlı olarak değişkenliği ve öngörülemezliği arz güvenliğini azaltmaktadır. Güvenilir verimli yüksek enerji arzı ve gelişmiş bir enerji sektörü, ekonominin gelişmesini ve rekabet gücünün artmasını sağlar $[20]$.

Yenilenebilir enerji kaynaklarına geçiş sürecinde, dağıtılmış yenilenebilir enerji (DRE) sistemlerinin teşvik edilmesi enerji güvenli açısından önem arz etmektedir. Enerji güvenliği açısından dağıtılmış yenilenebilir enerji sistemlerinin kullanımı nedeniyle kullanıcılara ekstra maliyetler getirecektir [21].

Yenilenebilir enerji projelerinin finansmanında teşvikler yer alıyor ise, proje karlılığının arttığını ve projenin geri ödeme süresinin kısa olduğunu tespit edilmiştir [22]. Fosil yakıtlar yerine yenilenebilir enerji kaynaklarına geçiş ekonomik ve teknolojik kavramlar olduğu gibi, aynı zamanda sosyal ve politik kavramlardır. Enerji geçişlerini başarıyla yönetmek için vatandaşların kabulü ve desteği şarttır [23]. Kişilerin çevresel kaygılarının çevre yanlısı davranış üzerinde olumlu etkileri bulunmaktadır [24]. Yerel halk1 fotovoltaik ve rüzgar enerjisi üretiminde yatırımcı haline getirmek, iklimin korunmasında ve halkın ekonomik gelişimine katkı sunmada etkili olacaktır. Toplumun enerji üretimine katkı sunması sağlanacak olan teşviklere bağlıdır [25]. 2015 Paris Sözleşmesi karbon emisyon hedefine ulaşmak için 2015-2050 yılları arasında 44 trilyon \$ yatırım yapılması gerekmektedir. Devletlerin ve kurumların yatırım bütçelerindeki kısıtlılık farklı sermaye gruplarının yatırım yapmaya teşvik edilmesi ile karşılanabilir. Finansal kurumlar, kamu hizmetleri veya işletmeler gibi geleneksel yatırımcılar düşük karbon teknolojileri (LCT) için sermaye sağlayıcıları olmakla birlikte, yerel halkında yatırımcı olarak sorumluluk üstlenmesi sağlanmalıdır [26]. Yerel yatırımcıların kuracağı tesisler 50 MW'tan küçük güçte ve dağıtılmış bir yapıya sahiptir [27]. Yenilenebilir enerji teknolojilerini yatırım yapan bölgesel yatırımcılar, diğer bölgesel aktörlerin yatırım kararı almasında örnek teşkil etmektedir [28].

Yenilenebilir enerji teknolojilerine geçiş faktörleri aşağıdaki etkenlere bağlıdır [29]:

- Bölgenin yenilenebilir enerji teknolojilerine geçiş oranına

- Bölgenin çevresel sorunlara karşı duyarlılığı 
- Yenilenebilir enerji sağlayıcılarının bölge sanayileşmesindeki payına

- Yönetmelik veya sübvansiyonlar yoluyla verilen devlet desteklerinin büyüklüklerine

- Enerji maliyetlerindeki artışlara

- Yenilenebilir enerji sağlayıcılarının sosyal sorumluluk anlayışına

Yenilenebilir enerji kaynaklarından enerji üretimi için teknolojik imkânlar ve ekonomik düzeylerinden kaynaklı farklar nedeniyle tek bir teşvik yapısı uygulanamaz. Ülkelerin, yenilenebilir enerji kaynaklarına yönelik uyguladıkları teşvikler vergi teşviklerini de kapsayan mali teşvikler ve üretim teşvikleri şeklinde gruplandırılmaktadır [30].

Yenilenebilir enerji kaynakları ile elektrik üretimi alanında yatırımcı firmaların dikkat ettiği bir konuda, yatırımlar esnasında sağlanan vergi muafiyetlerinin yanında, muafiyet sonrası uygulanacak vergi oranlarıdır. Bazı ülkeler yenilenebilir enerji alnındaki yatırımları teşvik için, uygulanacak vergi oranlarını düşürmeye veya tamamen ortadan kaldırmaya yönelik çalışmalar başlatmıştır [31].

Ülkelerin yenilenebilir enerji teşvik sistemleri Zuraidah ve arkadaşları tarafından 6 maddede özetlenmiştir [32,33];

1. Sabit fiyatla prim tarifesi: Üreticilerinin ürettikleri elektriği şebekeye belirli bir fiyattan satabileceklerini garanti eden sabit fiyatlı tarifeye sahip bir destekleme yöntemi (Feed in TariffFIT) veya üreticiler tarafından alınan toptan piyasa fiyatına bir bonus ekleyen prim tarifesidir (Feed in Premium-FIP).

2. Maliyet Dağıtımı: Yenilenebilir enerji sağlayıcısı ile enerji üretimi için sözleşme imzalanır. Maliyet ve gerçek piyasa fiyatı arasındaki fark, son kullanıcılara yansıtılır veya genellikle devlet bütçelerinden ödenir.

3. Maliyet Sınırlama: Her yıl bir destek politikası kapsamında verilebilecek toplam kapasiteyi veya toplam tarifeleri sinırlamaktadir.

4. Kontrat Süresi: Teşviklerin tedarikçiye ödenme süresi ülkeler arasında farklılıklar göstermektedir. Bazı ülkeler 10 yıl gibi bir süre için yüksek bir tarife sunarken, diğer ülkeler 25 yıla kadar daha düşük bir tarife sunmaktadır.

5. Tarife tutarı: Teşvik tarifesi belirlenirken üretim maliyeti, konum, sistem boyutu, enerji kaynağı, teknoloji gibi faktörler dikkate alınmaktadır.

6. Azalan Oran: Teşvikler zaman içinde azaltılarak yenilenebilir enerji teknolojilerinin ekonomik uygulanabilirliğine uyum sağlanmaktadır.

Kota zorunluluğu, sertifika sistemi ve vergilendirme sistemi ile yenilenebilir enerji teşvik edilebilir. Yenilenebilir enerji üretimi yapan kişi ve kurumlar, her birim enerji miktarı kadar sertifika almaktadır. [34]. Kota zorunluluğu, enerji üreticilerinin ürettikleri enerjinin belli bir kısmını yenilenebilir kaynaklardan tedarik etmesi yükümlülügüdür. Yenilebilir kaynak kullanarak üretilen enerjinin kota miktarını aşması durumunda, enerjinin fazla kısmı, kota miktarını dolduramayan üreticilere satılabilir [35].

Artımlı destek politikalarının önemi azalmaktadır. Enerji üretimi için verilen teşviklerin enerji piyasası risklerine karşı korunma amacıyla kullanılması ön plana çıkmaktadır [36].

Teşvik sistemlerinde FIT ve FIP en sık rastlanan programlardır. Ancak açık artırma planlarının son dönemde ön plana çıtığı görülmüştür. Avrupa Komisyonu, FIT'lerin cazip bir teşvik yöntemi olmaktan uzak olduğunu ifade etmekte ve piyasa fiyatını baz alan FIP gibi teşvik yöntemlerinin kullanılmasını önermektedir [37]. Maliyeti daha fazla olan yenilenebilir enerji teknolojilerine, daha yüksek teşvik uygulanması, ekonomik açıdan tezat teşkil etmektedir. Ancak yüksek maliyetli teknolojilerin zamanla popüler üretim sistemlerine dönüşebileceği öngörülmüş ve maliyeti yüksek olsa bile teşvik edilmesi gerektiği ifade edilmiştir [38]. Fosil yakıtlara verilen teşviklerin kaldırılması, yenilenebilir enerji teknolojileri için rekabet ortamını iyileştirmektedir [39]. 


\section{YÖNTEM}

Yenilenebilir enerji kaynakları ile enerji üretimi için verilen teşvikler ülkelerin çevre politikalarına, mali kaynaklarına, teknolojiye erişimlerine ve yerel enerji kaynaklarına bağlı olarak değişmektedir. $\mathrm{Bu}$ çalışmada farklı ülkelerin ve Türkiye'de yenilenebilir kaynaklar ile elektrik enerjisi üretimine yaklaşımları ve uyguladıkları teşvik sistemleri incelenmektedir. Isı üretimi ve nakliye için verilen teşvikler incelemenin dışında tutulmuştur.

\section{A. DANIMARKA'DA UYGULANAN ENERJİ TEŞVİKLERİ}

Danimarka 2018 yılı toplam enerji üretimi 586.574 TJ'ken, bu enerjinin 172.771 TJ değerindeki kısmı yenilenebilir enerji kaynaklarından sağlanmaktadır. Bu değer toplam enerjinin \%29'una karşıllık gelmektedir. Yenilenebilir enerji kaynakları kullanarak enerji üretiminde Danimarka örnek ülke olma durumuna gelmiştir. Şekil 2'de Danimarka yenilenebilir enerji üretimi grafiği görülmektedir.

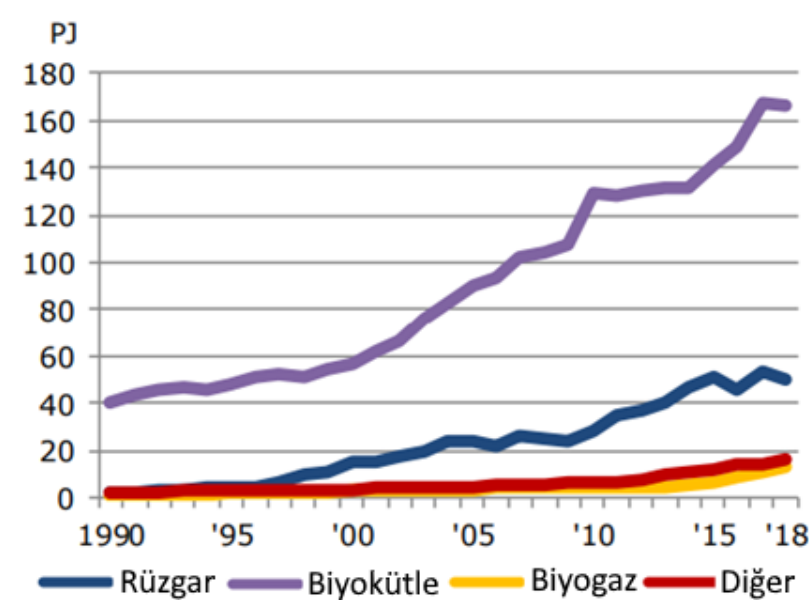

Şekil 2. Danimarka yenilenebilir enerji üretimi grafiği

Danimarka'nın bina, tarım ve ulaşımda yenilenebilir enerji kaynakları kullanımının artışı ve petrol bazlı kaynakların kullanımının azalmasından dolayı sera gazı emisyonlarını \%20 azaldığı tespit edilmiştir. Şekil 3'te Danimarka'nın 1990-2018 yılları arasında elektrik üretimi ve $\mathrm{CO}_{2}$ emisyonu gösterilmiştir [40].

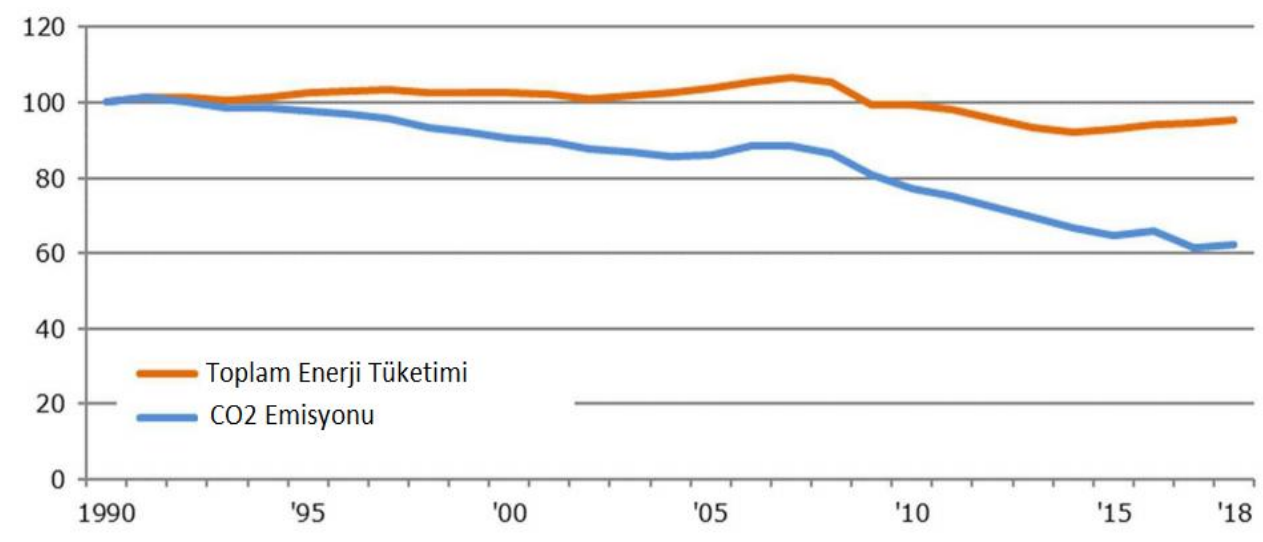

Şekil 3. Danimarka elektrik üretimi ve $\mathrm{CO}_{2}$ emisyon miktarının değişimi

Danimarka'da uygulanan ilk teşvik, 1979 y1lında rüzgar türbininin maliyetinin \%30'una hibe şeklinde verilmesidir. 1980'li yıllarda rüzgar enerjisi uygulamalarına 38 milyon Avro hibe olarak verildi ve teşvikler 1989'dan itibaren kademeli olarak azaltıldı. 1993 yılında sabit bir teşvik tarifesi yayınladı. 
1997 yılında rüzgar enerjisi kooperatiflerine katılan bireyler için rüzgar enerjisi üretiminden elde edilen gelir için vergi iadesi verildi. 2008 yılında Yenilenebilir Enerji Kaynaklarının Teşvik Edilmesi Yasası ile üreticiler lehine yapılan değişiklikler, 2009 yılında rüzgar enerjisi üretiminin artması şeklinde etkisini gösterdi [41].

Danimarka enerji modelinde yaklaşım, sektörel bileşenlere ve kavramlara odaklanmak yerine, sektörler arası ve kendi aralarında sinerji oluşturan sistemler arasındaki bağı kurmaktır. Kamu-özel iş birliği, yenilik ve atılımları desteklemektedir. Danimarka enerji modelinin üç esas unsura dayanır; enerji verimliliği, yenilenebilir enerji ve elektrik dağıtım sisteminin geliştirilmesi [42]. 2015 yılında Danimarka hükümeti 2050 yılında fosil yakıtları terk etmeyi taahhüt etmiştir. Danimarka iklim politikaları ile ilgili hedefleri kısmen belirli ulusal emellere ilişkin kararlardan ve kısmen de $A B$ ve BM'deki enerji alanındaki bir dizi uluslararası anlaşmaya uyma yükümlülüğünden kaynaklanmaktadır [43]. Danimarka'da, yenilenebilir kaynaklardan gelen elektrik, esas olarak prim tarifesi ve net ölçümleme yoluyla teşvik edilmektedir. Rüzgar ve güneş enerjisi PV kurulumları için prim tarifesi ihaleler yoluyla verilir. Ayrıca Danimarka ayrı bir devlet fonu aracılığıyla pilot rüzgar türbinlerin inşasını da desteklemektedir.

Danimarka'da uygulanan teşvikler:

1. İhale Teşvikleri: İhaleler, Danimarka Enerji Bakanlığı tarafından düzenlenmektedir. 2018-2019 yılı 136 milyon $€$ bütçe ayrılmış olup, kWh başına $2 €$ ct'tir.

2. Prim tarifesi: Deniz aşırı rüzgar tribünlerinin kurulması durumunda $3 € \mathrm{ct}$ bonus verilirken, 6.600 tam yük saati ve $5.6 \mathrm{MW}$ güç için maksimum $8 €$ ct olarak 20 y1l süre ile ödenmektedir. Gücü $10 \mathrm{~kW}$ 'a kadar Rüzgar Enerjisi tesisleri için 12 y1l boyunca $28 € \mathrm{ct} / \mathrm{kWh}$, gücü $10 \mathrm{~kW}$ $25 \mathrm{~kW}$ arasında olan tesisler $18 € \mathrm{ct} / \mathrm{kWh}$ prim ödenir.

Gazlaştırmadan saf biyogaz veya gaz kullanan tesisler için belirlenen maksimum sübvansiyon $11 € \mathrm{ct} / \mathrm{kWh}$ 'tır.

Biyogazın yanmasından üretilen elektrik oranı için 2020 yılında $\mathrm{kWh}$ başına $1,5 € \mathrm{ct} / \mathrm{kWh}$ garanti bonus verilmektedir. [44]

Hidroelektrik tesisler şebekeye bağlanma tarihinden itibaren 20 yll süre ile $1 € \mathrm{ct} / \mathrm{kWh}$ 'lik sabit destek alır.

3. Net-Ölçümleme: Danimarka'da tüketiciler, Kamu Hizmeti Yükümlülüğü (PSO) olarak adlandırılan bir ücret ödemekle yükümlüdür. Elektrik üreticileri tamamen veya kısmen Kamu Hizmeti Yükümlülüğ̈̈’nü ödemekten muaftır.

4. Kredi garantileri: Rüzgar ve güneş enerjisi santrali sahipleri santralinin inşasına kadar yürütülen fizibilite çalışmaları için $67.260 €$ kredi garantisi alabilir.

5. Vergi indirimleri: Yenilenebilir enerji kaynakları ile 1sıtma ve soğutma işlemleri yapan tedarikçilere vergi teşviki uygulanmaktadır. Vergi indirimi tutarı, şahıslardan muaf tutulan vergi oranına eşittir.[45, 46]

\section{B. İNGILTERE'DE UYGULANAN ENERJI TESVIKLLRİ}

İngiltere 2018 yılı toplam elektrik üretimi 352 TWh olmuştur. Toplam gücün \%33'ü yenilenebilir enerji kaynaklarından sağlanmakta olup, bu oran 116,16 TWh'lik enerjiye karşılık gelmektedir. Şekil 4'te İngiltere'nin elektrik üretim kaynakları grafiği görülmektedir [47]. İngiltere, solar PV ve rüzgar gibi yenilenebilir enerji teknolojilerini hayata geçirmede geç kalmıştır. 1990'da yerel olarak sahip olunan yenilenebilir enerji üretimi yok denecek kadar azken, 2000 yılından sonra yerel halk üretici olarak sisteme dahil edilmiş ve olumlu sonuçlar alınmıştır. 2014 yılında elektrik üretiminin \%19'u yenilenebilir kaynaklardan üretilmiştir. Toplam üretim değerinin \%9'u rüzgardan ve \%1'den azıda solar PV'den üretilmiştir. İngiltere'de özel sektör rüzgar enerjisi uygulamalarına odaklanmıştır .

2010 yılında yürürlüğe giren Enerji Yasası ile farklı teşvikler (FiT) ile enerji topluluklarının üretimdeki payı arttı. 2015 yılında küçük ölçekli yenilenebilir enerji üretim sınırı 5 MW'tan, 10 MW'a yükseltildi. Fizibilite değerlendirmeleri için yaklaşık $26.000 €$ hibe ve ön araştırma ve hazırlıklar için $167.000 €$ 'ya kadar kredi verilmiştir $[41,48]$. 
İngiltere 2002 yılında yenilenebilir enerjiye geçiş için 2020 yılına kadar bir takvim hazırladı. İngiltere Yenilenebilir enerjiye geçiş programı, yıllık \%56-76 arasında değişen düşük oranda gerçekleşmiştir. Program 2014 yılında revize edildi ve 2037 yılına kadar teşvikler devam ettirilmesine karar verildi. 5 MW'ın altında kapasiteye sahip küçük ve orta ölçekli RES'ler için 2010 yllında bir teşvik (FiT) programı başlatılmıştır [49].

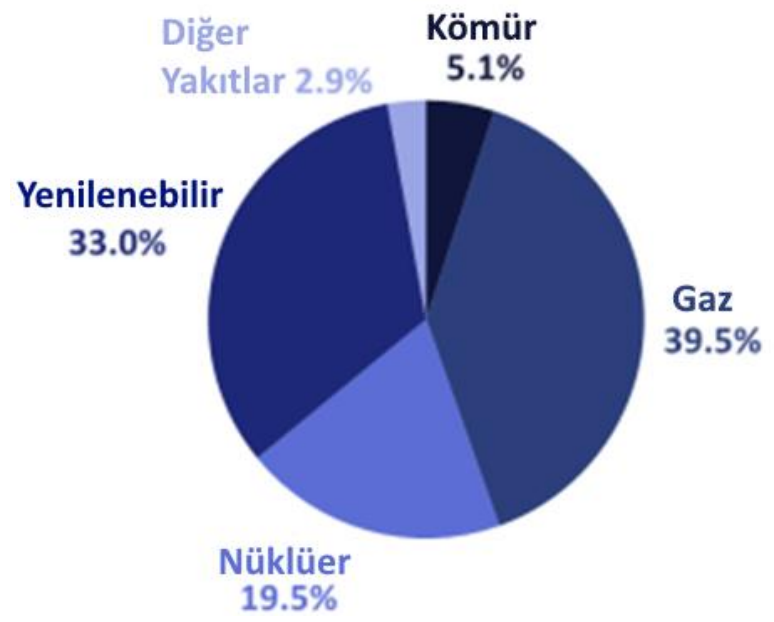

Şekil 4. Ingiltere 2018 yılı elektrik üretim kaynakları

FiT'den yararlanmalarının yanı sıra, solar PV sahipleri doğal olarak enerjilerinin bir kısmını veya tamamını kullanır veya fazlalığı elektrik şebekesine geri satabilir. Ev tipi güneş enerjisi sisteminin 30 kW'tan daha az bir güce sahip olması durumunda, ev sahibi üretim tarifesi üzerinden bir besleme primi alır. Hane halkı PV güneş enerjisi sisteminin gücü $30 \mathrm{~kW}$ 'tan fazlaysa, hane halkı fazlalığı toptan eşya fiyatını kullanarak elektrik piyasasında satabilir. Sabit şebeke tarifeleri ve yükümlülüklere bağlı olarak PV enerjinin çok fazla kullanılmasının hane halkı bütçesine çok yüksek katkı yaptığı tespit edilmiştir $[23,50]$.

Birleşik Krallık’ta, yenilenebilir kaynaklardan elektrik üretimi, kota zorunluluğu, sertifika sistemi ve vergi mekanizması açısından tarife sistemi, Fark Sözleşmeleri sistemi kombinasyonu ile desteklenmektedir [51]. Besleme tarifesine göre, tesisleri 5 MW'tan daha az kapasiteye sahip olan akredite üreticiler, elektriklerini Gaz ve Elektrik Piyasası Kurumu (Ofgem) tarafindan belirlenen sabit tarife oranlarında satabilirler. Bu plan sadece İngiltere, Galler ve İskoçya için geçerlidir.

İngiltere'de teşvikler 3 ana başlıkta toplanmaktadır. Teşvik tarifesi (FiT), Vergi düzenleme mekanizması ve ihaleler (Fark Sözleşmeleri)

1. Teşvik tarifesi (FiT): Rüzgar enerjisinde gücü $100 \mathrm{~kW}-1,5 \mathrm{MW}$ olan tesisler için $\mathrm{kWh}$ başına $1,94 €$ ct ve gücü $1,5 \mathrm{MW}$ 'ın üzerinde olan tesisler için $0,94 €$ ct olarak belirlenmiştir.

Güneş enerjisinde gücü $250 \mathrm{~kW}-1 \mathrm{MW}$ arasında olan tesisler için $\mathrm{kWh}$ başına $1,56 €$ ct, gücü 1 MW'tan büyük tesisler için $\mathrm{kWh}$ başına $0,22 €$ ct'tir.

Hidroelektrik sistemlerde gücü $500 \mathrm{~kW}-2 \mathrm{MW}$ arasında olan tesisler için kWh başına $6,98 € \mathrm{ct}$ ve gücü $2 \mathrm{MW}$ 'tan büyük tesisler için $6,98 €$ ct'tir.

2. Vergi düzenleme mekanizması: Yenilenebilir enerji üretimi vergi indirimleri iler teşvik edilmektedir. 250-1.000 kW arasında kurulu gücü bulunan solar enerji üretim tesisi vergi indirim oranı \%1,59'dur. $500-2000 \mathrm{~kW}$ arasında kurulu gücü bulunan hidroelektrik tesisinin vergi indirimi oranı $\% 6,06$ ' dır. Kurulu gücü $100-1500 \mathrm{~kW}$ arasında olan bir rüzgar santrali için uygulanan vergi indirim oran $\% 5,12$ 'dir [52].

3. İhale desteği: Fark sözleşmesi (CfD) olarak isimlendirilmekte olup İngiltere Hükümeti adına Düşük Karbon Sözleşmeleri Şirketi (LCCC) ile, yenilenebilir enerji kaynağından elektrik (RESE) enerjisi üreten üretici arasında yapılan bir hukuk sözleşmesidir. CfD, piyasa fiyatı ile üreticinin satı̧̧ fiyatı arasındaki farka dayanmaktadır. Üretici satış fiyatı, piyasa fiyatından düşük olması durumunda, RES-E üreticisine fiyat farkı ödenir [53]. 


\section{ALMANYA'DA UYGULANAN ENERJI TEŞVIKKLERİ}

Almanya'da 2019 yılında toplam 545,46 TWh elektrik üretilmiş olup, bunun 221,36 TWh'lik kısmı yenilenebilir enerji kaynakları oluşturmaktadır. Yenilenebilir enerji üretiminin \%40,6'lık kısmını karş1lı gelmektedir. Almanya'da elektrik üretimi için kullanılan kaynak çeşitliliği Şekil 5'te gösterilmiştir. [54].
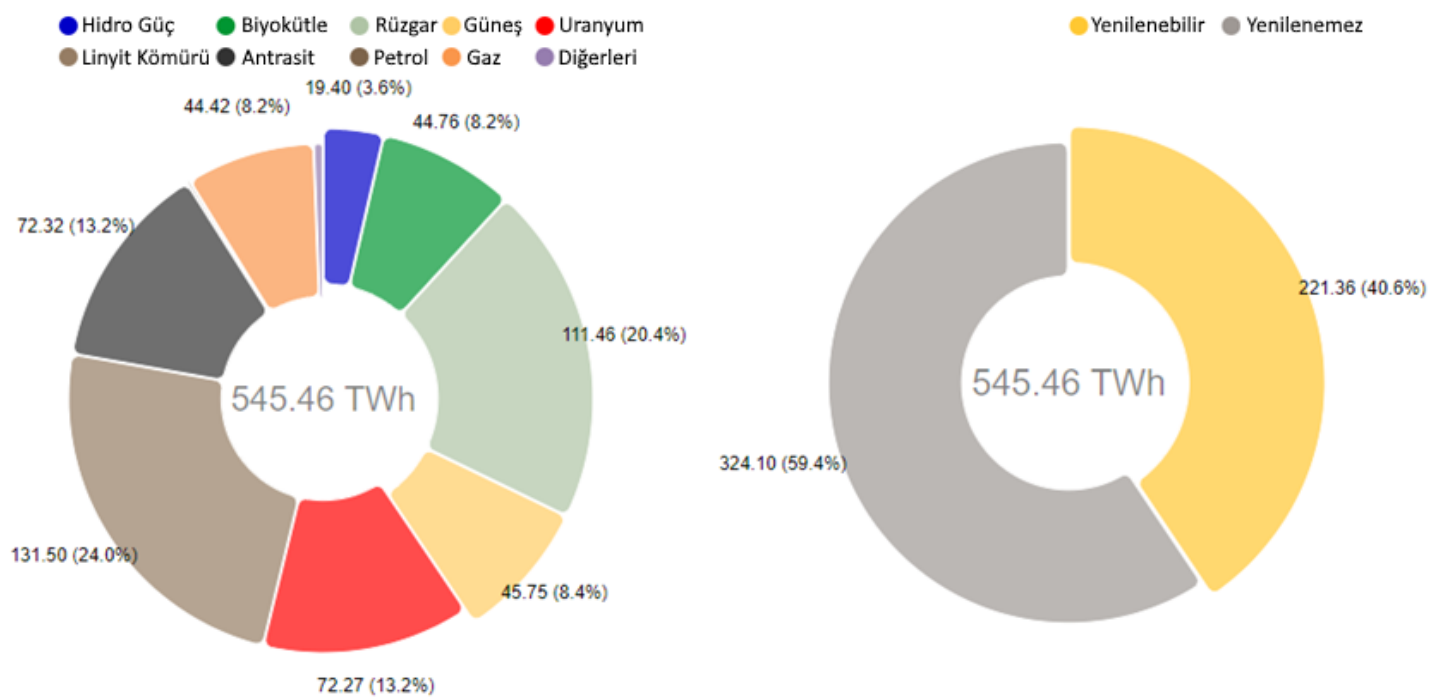

Şekil 5. 2018 yılı Almanya Elektrik Üretim Kaynakları

Almanya'da enerji dönüşümünde 3 parametre referans alınmaktadır. Bunlar enerji sisteminin maliyetleri, $\mathrm{CO}_{2}$ emisyonu ve temel enerji kaynağı tipidir. Yenilenebilir enerji kaynaklarından Biyokütle, rüzgar enerjisi ve PV kaynaklar, enerji üretiminde en büyük değere sahip olacak ana kaynaklardır. Biyokütle potansiyeli tüm ülke için ortak kaynaktır. 2015 yılında fosil yakıtlardan üretilen enerji miktarı 2500 TWh / yıl'dır. Aynı tarihte biyokütle'den 235 TWh / y1l, karadaki rüzgar santrallarından $526 \mathrm{TWh} /$ yıl $(\% 24)$, denizdeki rüzgar santrallarından $242 \mathrm{TWh} / \mathrm{y}$ ll $(\% 42,5)$ ve Fotovoltaik kaynaklardan üretilen elektrik miktarı $316 \mathrm{TWh} /$ yıl (\%12) olarak tespit edilmiştir [55,56].

Almanya'da uygulanan destek programları [57, 58]:

1. Standart Yenilenebilir Enerji Programı: Elektrik üretim tesislerinde yapılan yatırımlar için 10 yıllık sabit ve düşük faizli $(\% 1,05)$ krediler sağlamaktadır.

2. Açık Deniz Rüzgar Enerjisi Programı: Sunulan kredi düşük faizli ve 3 yılı geri ödemesiz olmak üzere, 20 yıl vadelidir. Genel dış sermaye gereksiniminin yüzde 50'sine kadar, proje başına maksimum 400 milyon $€$, 70'ine kadar, proje başına maksimum 700 milyon $€$.

3. Enerji ve Çevre Konsorsiyumu Kredi Programı: Kıyıdaki rüzgar santralleri ve foto voltaik tesisler için 4 milyar Avro'ya kadar bir konsorsiyum kredisi sunmaktadır.

4. Yenilenebilir Enerjide Depolama Programı: PV üretim sisteminin $30 \mathrm{~kW}$ 'a kadar sabit batarya depolama sistemlerinin kurulmasına \%100 oranında kredi desteği verilir.

5. İnovasyon Programı: Yenilenebilir enerji teknolojilerine yapılan yatırımların toplam yatırım maliyetlerinin \% 70'ine kadar kredi, \%30'una kadar sübvansiyon sağlar. Destek ilk 5 y1l geri ödemesiz olup, kredi vadesi 30 yıldır.

6. Teşvik (FiT) Tarifesi: Tarife miktarı kanunla belirlenir ve genellikle 20 yıl boyunca ödenir. Karada kurulu rüzgar enerjisi için $\mathrm{kWh}$ başına 4,66-8,38 € ct, denizde kurulu rüzgar tesisleri için kWh başına 3,9-1,4€ ct, güneş enerjisinde için kWh başına 8,91-12,70 € ct, hidroelektrik sistemlerde $\mathrm{kWh}$ başına 3,47-12,40 € ct, biyokütle ile enerji üretiminde 5,71-13,32 $€$ ct teşvik ödemesi yapılmaktadır.

7. İhale Yapısı: $750 \mathrm{~kW}$ 'dan başlayan kara ve deniz rüzgar, güneş enerjisi projeleri, 150 $\mathrm{kW}$ 'dan başlayan biyokütle tesisleri enerji üreticilerine ihale ile verilmektedir. Verilecek teşvikler ihale esnasında üreticilere bildirilir. 


\section{TÜRKIYYE'DE UYGULANAN ENERJİ TEŞVIKLERİ}

Türkiye'nin 2019 yılı elektrik enerjisi kurulu gücü 90.421 MW'tır. 2018 y1lında 303,9 milyon MWh elektrik üretimi gerçekleştirilmiştir. Toplam elektrik üretiminin \%37,3'ü kömürden, \%29,8'i doğal gazdan, \%19,8'i hidrolik enerjiden, \%6,6's1 rüzgârdan, \%2,6's1 güneşten, \%2,5'i jeotermal enerjiden ve $\% 1,4$ 'ü diğer kaynaklardan elde edilmiştir [59]. Türkiye 2018 yılı elektrik enerjisi üretim oranları Şekil 6 'da verilmiştir.

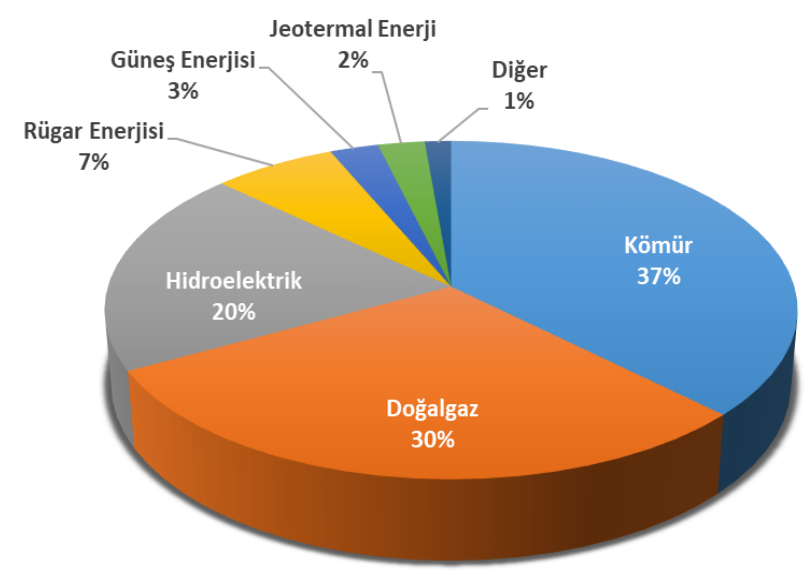

Şekil 6. Türkiye 2018 yll elektrik enerjisi üretim oranları

Türkiye'de yenilenebilir enerji kaynaklarının elektrik enerjisi üretimi amaçlı kullanımının yaygınlaştırılması, bu kaynakların güvenilir, ekonomik ve kaliteli biçimde ekonomiye kazandırılması, kaynak çeşitliliğinin artırılması, sera gazı emisyonlarının azaltılması, atıkların değerlendirilmesi, çevrenin korunması ve bu amaçların gerçekleştirilmesinde ihtiyaç duyulan imalat sektörünün geliştirilmesi amacı ile, 5346 numaralı, "Yenilenebilir Enerji Kaynaklarının Elektrik Enerjisi Üretimi Amaçlı Kullanımına İlişkin Kanun”, 18.05.2005 tarih ve 25819 sayılı Resmi Gazete'de yayınlanarak yürürlüğe girmiştir [60].

Ayrıca Bakanlar Kurulu 2013 yılında 5625 sayılı karar ile yenilenebilir enerji kaynaklarına dayalı üretim faaliyeti gösteren tesisler için uygulanacak fiyat ve süreleri belirlemiştir. 5346 numaralı kanun ve 5625 sayılı yönetmelikte, yenilenebilir enerji kaynaklarından enerji üretimi için üreticilere ödenecek teşvikler belirlenmiştir. Hidrolik veya rüzgâr enerjisine dayalı üretim tesislerinde üretilen elektrik enerjisi için $\mathrm{kWh}$ başına 7,3 \$ ct, jeotermal enerjisine dayalı üretim tesisi için $\mathrm{kWh}$ başına 10,5 \$ ct, biyokütle veya güneş enerjisine dayalı üretim tesisi $\mathrm{kWh}$ başına 13,3 \$ ct teşvik verilmesi kararlaştırılmıştır. Teşvikler 18/5/2005 tarihi ile 31/12/2020 tarihleri arasında işletmeye alınmış veya alınacak olan Yenilenebilir Enerji Kaynakları Destekleme Mekanizmasına (YEKDEM) tabi ve YEK Belgeli üretim lisans1 sahiplerine 10 yıl süre ile uygulanmaktadır [61].

2016 y1lında yenilenebilir enerji kaynaklarından elektrik enerjisi üreten tesislerde kullanılan yerli aksamın desteklenmesi başlıklı yönetmelik yayınlandı. Yenilenebilir enerji kaynaklarından elektrik enerjisi üreten tesislerde kullanılmak üzere Türkiye'de üretilen aksamın veya parçaların belgelendirilmesi, üretilmesi, denetlenmesi ve teşvik miktarının belirlenmesi amaçlanmıştır. Yerli üretim teşviği kapsamında 18/5/2005 ile 31/12/2020 tarihleri arasında lisanslı tesislerde kullanılmakta olan mekanik ve elektromekanik malzemelerin en az yönetmelikte tanımlanan oranlarda yerli üretim olması durumunda, tesiste üretilecek elektrik enerjisi için 5 yıl süreyle ilave fiyat verilmektedir. Tesisin herhangi bir ünitesinde kullanılan yerli malzeme oranının tesisisin diğer tüm kısımlarında da aynı olması zorunludur. Tablo 1'de yerli aksan ve bileşenleri kullanılarak elektrik üreten hidroelektrik, rüzgar ve fotovoltaik santrallerde kWh başına verilen teşvik miktarı \$ ct olarak gösterilmiştir [62].

5346 sayılı kanunda yenilenebilir enerji kaynakları ile üretim santrallerin kurulu bulunduğu arazilerden, ulaşım yollarından, lisanslarında, enerji nakil hatlarındaki yatırımın ve işletme giderlerinin ilk on yılında 
izin, kira, irtifak hakk1 ve kullanma izni bedellerinde \%85 indirim uygulanmaktadır. Hidroelektrik üretim tesislerinin kurulu bulunduğu su biriktirme alanlarının Hazine'ye ait kısımları bedelsiz olarak üreticinin kullanımına verilmektedir. Kendi ihtiyacına yönelik Yenilenebilir enerji kaynakları ile 1000 kV'a kadar elektrik gerçek ve tüzel kişilerden projeler için DSİ veya Yenilenebilir Enerji Genel Müdürlügü tarafından hizmet bedelleri alınmamaktadır [60].

Tablo 1. Yenilenebilir enerji üretiminde (Hidroelektrik, Rüzgar, Fotovoltaik) kullanılan aksan ve parçaları için verilen yerli üretim teşvikleri

\begin{tabular}{|c|c|c|c|c|c|}
\hline $\begin{array}{l}\text { Santral } \\
\text { Tipi }\end{array}$ & $\begin{array}{l}\text { İmal Edilen } \\
\text { Aksam }\end{array}$ & & Bütünleştirici Parçalar & $\begin{array}{c}\text { Parça } \\
\text { Aksan } \\
\text { İçindeki } \\
\text { Oranı }\end{array}$ & $\begin{array}{c}\text { Yerli Katkı } \\
\text { Illavesi } \\
(\$ \text { ct } / \mathbf{k W h})\end{array}$ \\
\hline \multirow{8}{*}{ 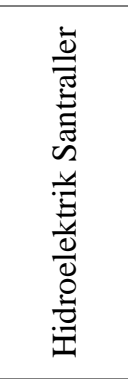 } & \multirow{6}{*}{ 1.Türbin } & 1.1 & $\begin{array}{l}\text { Salyangoz veya türbin muhafaza gövdesi ve } \\
\text { dağıtıcı boru }\end{array}$ & $\% 15$ & \multirow{6}{*}{1,3} \\
\hline & & 1.2 & Türbin Çarkı ve varsa Türbin Mili & $\% 35$ & \\
\hline & & 1.3 & Ayar kanatları veya nozul & $\% 20$ & \\
\hline & & 1.4 & Servomotor ve varsa ayar çemberi & $\% 10$ & \\
\hline & & 1.5 & Governor (Hız regülâtörü) & $\% 10$ & \\
\hline & & 1.6 & Emme borusu veya zemine bağlantıları & $\% 10$ & \\
\hline & \multirow{2}{*}{$\begin{array}{l}\text { 2.Jeneratör ve güç } \\
\text { elektroniği }\end{array}$} & 2.1 & Jeneratör & $\% 70$ & \multirow{2}{*}{1,0} \\
\hline & & 2.2 & Güç elektroniği & $\% 30$ & \\
\hline \multirow{14}{*}{ 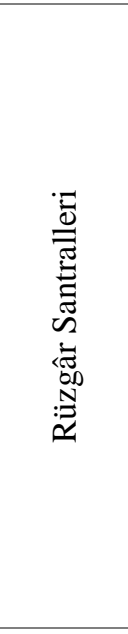 } & 1. Kanat & 1.1 & Kanat ve rotor göbeği bağlantıları & $\% 100$ & 0,8 \\
\hline & \multirow{2}{*}{$\begin{array}{l}\text { 2. Jeneratör ve } \\
\text { güç elektroniği }\end{array}$} & 2.1 & Jeneratör & $\% 70$ & \multirow{2}{*}{1,0} \\
\hline & & 2.2 & Güç elektroniğgi & $\% 30$ & \\
\hline & \multirow{2}{*}{ 3. Türbin kulesi } & 3.1 & Rotor ve Nasel gruplarını taşıyan kule & $\% 80$ & \multirow{2}{*}{0,6} \\
\hline & & 3.2 & Kule Bağlantı Elemanları & $\% 20$ & \\
\hline & \multirow{9}{*}{$\begin{array}{l}\text { 4. Rotor ve nasel } \\
\text { gruplarındaki } \\
\text { mekanik aksamın } \\
\text { tamamı }\end{array}$} & 4.1 & Rotor göbek bloğu & $\% 15$ & \multirow{9}{*}{1,3} \\
\hline & & 4.2 & Nasel ve Rotor göbek bloğu diş kabinleri & $\% 5$ & \\
\hline & & 4.3 & Kanat yönlendirme sistemi & $\% 10$ & \\
\hline & & 4.4 & Nasel yönlendirme mekanizması & $\% 10$ & \\
\hline & & 4.5 & Ana veya sabit mil & $\% 10$ & \\
\hline & & 4.6 & Ana mil yatağ1 ve varsa yatak bloğu & $\% 5$ & \\
\hline & & 4.7 & Şase & $\% 10$ & \\
\hline & & 4.8 & $\begin{array}{l}\text { Mekanik ve aerodinamik fren diskleri ve } \\
\text { hidrolik kontrol sistemleri }\end{array}$ & $\% 5$ & \\
\hline & & 4.9 & Dişli kutulu hız dönüştürücüsü & $\% 30$ & \\
\hline \multirow{9}{*}{ 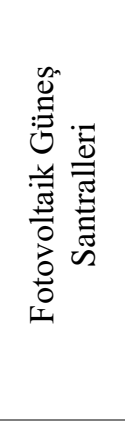 } & \multirow[t]{2}{*}{$\begin{array}{l}\text { 1. PV panel } \\
\text { montaj mekaniği }\end{array}$} & 1.1 & Taşıyıcı yapı & $\% 55$ & \multirow[t]{2}{*}{0,8} \\
\hline & & 1.2 & Elektriksel bağlantılar & $\% 45$ & \\
\hline & \multirow{2}{*}{ 2.PV modülleri } & 2.1 & Kristal esaslı PV modüller & $\% 100$ & \multirow{2}{*}{1,3} \\
\hline & & 2.2 & Odaklayıcılı PV modüller(CPV) & $\% 100$ & \\
\hline & \multirow{3}{*}{$\begin{array}{l}\text { 3.PV modülü } \\
\text { hücreleri }\end{array}$} & 3.1 & Kristal esaslı PV hücreler & $\% 100$ & \multirow{3}{*}{3,5} \\
\hline & & 3.2 & İnce film esaslı PV hücreler & $\% 100$ & \\
\hline & & 3.3 & Odaklayıcılı PV hücreler & $\% 100$ & \\
\hline & 4. İnvertör & 4.1 & İnvertör & $\% 100$ & 0,6 \\
\hline & 5. Odak malzeme & 5.1 & Odak malzeme & $\% 100$ & 0,5 \\
\hline
\end{tabular}

6446 Sayılı Elektrik Piyasası Kanunu'na göre yenilenebilir enerji kaynakları ile enerji üretmek için lisans başvurusunda ödenmesi gereken bedelin \%10'u ödenir. Tesis tamamlanma tarihini takip eden sekiz yıl süresince yıllık lisans bedeli ödemesi yapılmamaktadır. Ar-ge faaliyetleri yürüten tüzel kişilere TEİAŞ ve/veya dağıtım lisansı sahibi tüzel kişilerin uygun bulması ve üretilecek elektriğin ticarete konu olmaması şartı ile lisanssız elektrik üretimi yapabilmesi için izin verilmektedir. 31 Aralık 2020 tarihine kadar ilk defa işletmeye girecek üretim lisansı sahibi tüzel kişilere ait üretim tesislerinin, işletmeye giriş tarihinden itibaren 5 yıl süresince iletim sistemi, sistem kullanım bedellerinde yüzde 50 indirim yapılır. [63]. 
2012 yılında kabul edilen 3305 sayılı Bakanlar Kurulu kararına göre Türkiye gelişmişlik açısından 6 bölgeye ayrılmıştır. Yenilenebilir enerji kaynakları ile elektrik üretimi konusunda yapılacak yatırımlara verilecek teşviklerde bu bölgeler referans olarak alınmakta ve uygulanan teşvik yöntemleri bölgelere göre farkl11ıklar göstermektedir. Tablo 2'de 1 Ocak 2021'den itibaren geçerli olacak yatırım teşvik bölgelerindeki iller ve teşvik süreleri görülmektedir [64].

Tablo 2. Türkiye yatırım teşvik bölgeleri, illeri ve süreleri [65]

\begin{tabular}{|c|c|c|c|c|c|}
\hline 1. Bölge & 2. Bölge & 3. Bölge & 4. Bölge & 5. Bölge & 6. Bölge \\
\hline 2 Y1l Süreli & 3 Yil Süreli & 5 Yil Süreli & 6 Y11 Süreli & 7 Yıl Süreli & 10 Y1l Süreli \\
\hline Ankara & Aydın & Adana & Afyonkarahisar & Bayburt & Adiyaman \\
\hline Antalya & Balıkesir & Burdur & Aksaray & Çankırı & A ğgr1 \\
\hline Bursa & Bilecik & Düzce & Amasya & Erzurum & Ardahan \\
\hline Eskişehir & Bolu & Gaziantep & Artvin & Giresun & Batman \\
\hline İstanbul & Çanakkale & Karaman & Bartın & Gümüşhane & Bingöl \\
\hline İzmir & Denizli & Kırıkkale & Çorum & Kahramanmaraş & Bitlis \\
\hline Kocaeli & Edirne & Kütahya & Elazı $\breve{g}$ & Kilis & Diyarbakır \\
\hline Muğla & Isparta & Mersin & Erzincan & Niğde & Hakkari \\
\hline \multirow[t]{8}{*}{ Tekirdağ } & Karabük & Samsun & Hatay & Ordu & Iğdır \\
\hline & Kayseri & Trabzon & Kastamonu & Osmaniye & Kars \\
\hline & Kirklareli & Rize & Kırşehir & Sinop & Mardin \\
\hline & Konya & Uşak & Malatya & Tokat & Muş \\
\hline & Manisa & Zonguldak & Nevşehir & Tunceli & Siirt \\
\hline & Sakarya & & Sivas & Yozgat & Şanlıurfa \\
\hline & Yalova & & & & Şırnak \\
\hline & & & & & Van \\
\hline
\end{tabular}

Türkiye yatırım teşvik bölgelerinde yenilenebilir enerji kaynaklarından elektrik üretimi için uygulanan yöntemler 4 başlık altında gruplandırılmaktadır. Tablo 3 'te bölgesel teşvikler görülmektedir [66];

Tablo 3. Türkiye'de uygulanan teşvik yöntem uygulamaları

\begin{tabular}{|c|c|c|c|}
\hline $\begin{array}{l}\text { 1. Genel Teşvik } \\
\text { Uygulamaları }\end{array}$ & $\begin{array}{l}\text { 2. Bölgesel Tessvik } \\
\text { Uygulamaları }\end{array}$ & $\begin{array}{l}\text { 3. Büyük Ölçekli } \\
\text { Yatırımların Teşviki }\end{array}$ & $\begin{array}{l}\text { 4. Stratejik Yatırımların } \\
\text { Teşviki }\end{array}$ \\
\hline KDV İstisnas1 & KDV İstisnas 1 & KDV İstisnas1 & KDV İstisnas1 \\
\hline $\begin{array}{l}\text { Gümrük Vergisi } \\
\text { Muafiyeti }\end{array}$ & $\begin{array}{l}\text { Gümrük Vergisi } \\
\text { Muafiyeti }\end{array}$ & $\begin{array}{l}\text { Gümrük Vergisi } \\
\text { Muafiyeti }\end{array}$ & Gümrük Vergisi Muafiyeti \\
\hline- & Vergi İndirimi & Vergi İndirimi & Vergi İndirimi \\
\hline - & $\begin{array}{l}\text { Sigorta Primi İşveren } \\
\text { Hissesi Desteği }\end{array}$ & $\begin{array}{l}\text { Sigorta Primi İşveren } \\
\text { Hissesi Desteği }\end{array}$ & $\begin{array}{l}\text { Sigorta Primi İşveren Hissesi } \\
\text { Desteği }\end{array}$ \\
\hline $\begin{array}{l}\text { Gelir Vergisi } \\
\text { Stopaj1 Desteği } \\
\text { (6. bölge için } \\
\text { geçerli) }\end{array}$ & $\begin{array}{l}\text { Gelir Vergisi Stopaj1 } 1 \\
\text { Desteği (6. bölge için } \\
\text { geçerli) }\end{array}$ & $\begin{array}{l}\text { Gelir Vergisi Stopaj1 } 1 \\
\text { Desteği (6. bölge için } \\
\text { geçerli) }\end{array}$ & $\begin{array}{l}\text { Gelir Vergisi Stopaj1 Desteği (6. } \\
\text { bölge için geçerli) }\end{array}$ \\
\hline- & $\begin{array}{l}\text { Sigorta Primi Desteği } \\
\text { (6. bölge için geçerli) }\end{array}$ & $\begin{array}{l}\text { Sigorta Primi Desteği (6. } \\
\text { bölge için geçerli) }\end{array}$ & $\begin{array}{l}\text { Sigorta Primi Desteği (6. bölge } \\
\text { için geçerli) }\end{array}$ \\
\hline- & $\begin{array}{l}\text { Faiz Desteği }(3,4,5 \\
\text { ve } 6 \text {. bölgeler için } \\
\text { geçerli) }\end{array}$ & - & $\begin{array}{l}\text { Faiz Desteği }(3,4,5 \text { ve } 6 \text {. bölgeler } \\
\text { için geçerli) }\end{array}$ \\
\hline- & Yatırım Yeri Tahsisi & Yatırım Yeri Tahsisi & Yatırım Yeri Tahsisi \\
\hline- & - & - & $\begin{array}{l}\text { Sabit yatırım tutarı } 500 \text { Milyon } \\
\text { TL üzerinde olan } 1 \text {. Ve } 2 \text {. } \\
\text { Bölgelerde } 1 \text { milyon } €, 3 ., 4 ., 5 \text {. Ve } \\
6 \text {. Bölgelerde } 500 \text { bin } €\end{array}$ \\
\hline
\end{tabular}


Türkiye'nin kurulu elektrik gücü 19 yılda \%334,7 oranında artarak 2019 yılında 91.267 MW'a ulaşmıştır. Aynı dönem içinde yenilenebilir enerji kaynaklarından elektrik üretimi artış oranı \%395,6'dır. Yenilenebilir enerji kaynakları kullanılarak gerçekleştirilen elektrik üretimindeki hızlı yükseliş yenilenebilir enerji kaynaklı enerji üretim miktarının toplam elektrik üretimindeki payını $\% 48,6$ 'ya çıkmasını sağlamıştır. Türkiye'de yenilenebilir kaynaklarından üretilen güç ve toplam elektrik gücü Tablo 4'te görülmektedir [71].

Tablo 4. Türkiye yenilenebilir kaynaklı kurulu elektrik gücü ve toplam toplam güç (MW)

\begin{tabular}{lcccccccc}
\hline Yıllar & Hidrolik & Jeotermal & Rüzgar & Güneş & Biyokütle & $\begin{array}{c}\text { Yenilenebilir } \\
\text { Kurulu Gücï }\end{array}$ & $\begin{array}{c}\text { Toplam } \\
\text { Kurulu Yenilenebilir } \\
\text { Güç }\end{array}$ & Enerji Payı \\
\hline 2000 & $11.175,2$ & 17,5 & 18,9 & & 10,0 & $11.221,6$ & $27.264,1$ & $\% 41,2$ \\
\hline 2001 & $11.672,9$ & 17,5 & 18,9 & & 10,0 & $11.719,3$ & $28.332,4$ & $\% 41,4$ \\
\hline 2002 & $12.240,9$ & 17,5 & 18,9 & & 13,8 & $12.291,1$ & $31.845,8$ & $\% 38,6$ \\
\hline 2003 & $12.578,7$ & 15,0 & 18,9 & & 13,8 & $12.626,4$ & $35.587,0$ & $\% 35,5$ \\
\hline 2004 & $12.645,4$ & 15,0 & 18,9 & & 13,8 & $12.693,1$ & $36.824,0$ & $\% 34,5$ \\
\hline 2005 & $12.906,1$ & 15,0 & 20,1 & & 13,8 & $12.955,0$ & $38.843,5$ & $\% 33,4$ \\
\hline 2006 & $13.062,7$ & 23,0 & 59,0 & & 19,8 & $13.164,4$ & $40.564,8$ & $\% 32,5$ \\
\hline 2007 & $13.394,9$ & 23,0 & 147,5 & & 21,2 & $13.586,6$ & $40.835,7$ & $\% 33,3$ \\
\hline 2008 & $13.828,7$ & 29,8 & 363,7 & & 38,2 & $14.260,4$ & $41.817,2$ & $\% 34,1$ \\
\hline 2009 & $14.553,3$ & 77,2 & 791,6 & & 65,0 & $15.487,1$ & $44.761,2$ & $\% 34,6$ \\
\hline 2010 & $15.831,2$ & 94,2 & $1.320,2$ & & 85,7 & $17.331,3$ & $49.524,1$ & $\% 35,0$ \\
\hline 2011 & $17.137,1$ & 114,2 & $1.728,7$ & & 104,2 & $19.084,2$ & $52.911,1$ & $\% 36,1$ \\
\hline 2012 & $19.609,4$ & 162,2 & $2.260,6$ & & 147,3 & $22.179,5$ & $57.059,4$ & $\% 38,9$ \\
\hline 2013 & $22.289,0$ & 310,8 & $2.759,7$ & & 178,0 & $25.537,5$ & $64.007,5$ & $\% 39,9$ \\
\hline 2014 & $23.643,2$ & 404,9 & $3.629,7$ & 40,2 & 227,0 & $27.945,0$ & $69.519,8$ & $\% 40,2$ \\
\hline 2015 & $25.867,8$ & 623,9 & $4.503,2$ & 248,8 & 277,1 & $31.520,8$ & $73.146,7$ & $\% 43,1$ \\
\hline 2016 & $26.681,1$ & 820,9 & $5.751,3$ & 832,5 & 363,8 & $34.449,6$ & $78.497,4$ & $\% 43,9$ \\
\hline 2017 & $27.273,1$ & $1.063,7$ & $6.516,2$ & $3.420,7$ & 477,4 & $38.751,1$ & $85.200,0$ & $\% 45,5$ \\
\hline 2018 & $28.291,4$ & $1.282,5$ & $7.005,4$ & $5.062,8$ & 621,9 & $42.264,0$ & $88.550,8$ & $\% 47,7$ \\
\hline 2019 & $28.503,0$ & $1.514,7$ & $7.591,2$ & $5.995,2$ & 791,3 & $44.395,3$ & $91.267,0$ & $\% 48,6$ \\
\hline
\end{tabular}

\section{SONUC VE ÖNERI}

Yenilenebilir enerji kaynaklarına yapılan yatırımlar $\mathrm{CO}_{2}$ emisyonunun ve olumsuz çevresel etkilerin azalmasına katkı sunacaktır. Hükümetlerin yüksek maliyetli yenilenebilir enerji üretim sistemlerine mali kaynak yaratması doğrudan enerji fiyatlarına ve dönüşüm hızına olumlu etki etmektedir. Özel sektörün enerji üretimi, enerji teknolojilerine yatırım yapması bu dönüşüme ivme kazandırmaktadır.

Teşvikler genel olarak doğrudan üreticiden satın alınan elektrik miktarına bağlı olarak sabit prim (FiT) şeklinde verilse de son dönemde rekabeti arttırma etkisine sahip olan sabit primin üzerine ekstra prim verilmesi (FiP) cazip hale gelmiştir. Sabit veya primli sistemlerle satın alma garantileri verilerek yatırımcilar korunmaktadır.

Ülkemizde yenilenebilir enerji kaynaklarına verilen teşviklerin hedefine ulaştığını, yenilenebilir enerji kaynaklarından üretilen elektrik miktarının, toplam elektrik üretimi içindeki payının \%48,6'ya ulaşmasından anlaşılmaktadır.

Enerji üretiminde yerel kaynakların kullanılması, dağıtılmış enerji çeşitliliğini arttırmakta ve ülkelerin dışa bağımlılığı azalırken, enerji güvenliğini arttırmaktadır. Yenilenebilir enerji kaynaklarına yapılacak yatırım ile yeni çalışma alanları oluşmakta ve elektrik enerjisi arzını karşılamanın yanı sıra dolaylı olarak ekonomik katkı yapacak kanallar geliştirilmektedir. Danimarka, İngiltere ve Almanya örneklerinde 
olduğu gibi tüm vatandaşların elektrik üreticisi konumuna geçirilmesi hane gelirine katkı sunarken, hükümetlerin enerji ve iletim yatırımlarından tasarruf etmesini sağlamaktadır.

Günümüzün en rekabetçi teşvik sistemi ihale yöntemi olarak karşımıza çıkmaktadır. Ülkemizde de YEKA olarak hayata geçirilen ihale yöntemi ile enerji ihtiyacı piyasa değerinden çok daha ucuza sağlanırken, enerji piyasası aktörlerinin yeni alanlarda faaliyet gösterme gayreti teşviklerle desteklenmekte ve yüksek yatırım maliyetlerine katlanan girişimcilerin yatırımları güvence altına alınmaktadir.

Yenilenebilir enerji yatırımlarının artması için hükümetler coğrafi koşulları dikkate alarak enerji yatırımcılarına kredi, vergi indirimi, sübvansiyon ve hibe desteği gibi teşvikler sunmalıdır.

Ülkemizde de yenilenebilir enerji kaynakları kullanılarak elektrik üretimi oranının arttırılması çevresel kazanımlarımızın yanında, kaynaklarımızın çeşitlendirilmesini sağlarken, ithal menşeili doğalgaza olan bağımlılı̆̆ımızı azaltmaktadır. Yenilenebilir enerji kaynakları ile enerji üretimi ve gerekli teknolojilerin geliştirilmesi için teşviklerin planlı şekilde devam etmesi sürdürülebilirlik açısından önem arz etmektedir. Yenilenebilir enerji teknolojilerine yapılan yatırımlar ile yerlileşmenin sağlanması, gelecekte dünya pazarından pay almamızı sağlayacaktır.

\section{KAYNAKLAR}

[1] O. Ellabban, H. Abu-Rub, F. Blaabjerg, "Renewable Energy Resources: Current Status, Future Prospects And Their Enabling Technology," Renewable and Sustainable Energy Reviews, c. 39, ss. 748764, 2014.

[2] B. K. Bose, "Global Warming: Energy, Environmental Pollution, And The Impact Of Power Electronics," IEEE Industrial Electronics Magazine, c. 4, s. 1, ss. 6-17, 2010.

[3] M. Babiker, J.M. Reilly, H.D. Jacoby, "The Kyoto Protocol And Developing Countries," Energy Policy, c. 28, s. 8, ss. 525-536, 2000.

[4] The Kyoto Protocol - Status of Ratification, UNFCCC Sites And Platforms. [Çevrimiçi]. Erişim: https://unfccc.int/process/the-kyoto-protocol/status-of-ratification Erişim Tarihi: 01.12.2019.

[5] D. Gielen, F. Boshell, D. Saygin, M.D. Bazilian, N. Wagner, R. Gorini, "The Role Of Renewable Energy In The Global Energy Transformation," Energy Strategy Reviews, c. 24, ss. 38-50, 2019.

[6] EU, Directive 2001/77/EC on the Promotion of Electricity Produced from Renewable Energy Sources in the Internal Electricity Market, (27 Ekim, 2001). [Çevrimiçi]. Erişim: https://eurlex.europa.eu/legal-content/EN/TXT/?uri=CELEX\%3A32001L0077

[7] A. Acaravci, S. Erdoğan, "Environment and Economic Growth Nexus: An Empirical Analyses for Selected Countries," Eskişehir Osmangazi University Journal of Economics and Administrative Sciences, c. 13, s. 1, ss. 53-64, 2018.

[8] EU, Directive 2009/28/EC On The Promotion Of The Use Of Energy From Renewable Sources And Amending And Subsequently Repealing Directives 2001/77/EC And 2003/30/EC. 5 Haziran, 2006. [Çevrimiçi]. Erişim https://eur-lex.europa.eu/legal-content/EN/ALL/?uri=CELEX\%3A32009L0028

[9] BP, Statistical Review of World Energy 2020 | 69th edition, [Çevrimiçi]. Erişim: https://www.bp.com/content/dam/bp/business-sites/en/global/corporate/pdfs/energy-

economics/statistical-review/bp-stats-review-2020-full-report.pdf 
[10] Eurostat Statistics Explained, "Electricity Price Statistics," [Çevrimiçi]. Erişim: https://ec.europa.eu/eurostat/statistics-explained/index.php/Electricity_price_statistics Erişim Tarihi: 06.12.2020.

[11] S. Jenniches, "Assessing The Regional Economic Impacts Of Renewable Energy Sources - A Literature Review," Renewable and Sustainable Energy Reviews, c. 93, ss. 35-51, 2018.

[12] S. Bell, "The Renewable Energy Transition Energy Path Divergence, Increasing Returns and Mutually Reinforcing Leads in the State-Market Symbiosis," New Political Economy, c. 25, s. 1, ss. 57$71,2020$.

[13] Z. Ngadiron, N.H. Radzi, "Feed-In-Tariff And Competitive Auctions As Support Mechanism For Renewable Energy: A Review," ARPN Journal of Engineering and Applied Sciences, c. 11, s. 14, ss. 8939-8946, 2016.

[14] M. Woerter, T. Stucki, S. Arvanitis, C. Rammer, M. Peneder, "The Adoption Of Green Energy Technologies: The Role Of Policies In Austria, Germany And Switzerland," Green Energy, c. 14, s. 14, ss. 1192-1208, 2017.

[15] T.N. Sequeira, M.S. Santos, "Renewable Energy And Politics: A Systematic Review And New Evidence," Journal of Cleaner Production, c. 192, ss. 553-568, 2018.

[16] A. Çelikkaya, "Dünyada Yenilenebilir Enerji Yatırımlarına Sağlanan Vergi Teşviklerinin Değerlendirilmesi," Afyon Kocatepe Üniversitesi Sosyal Bilimler Dergisi, c. 20, s. 1, ss. 357-384, 2018.

[17] A.J. Armstrong, J. Hamrin, "The Renewable Energy Policy Manual," [Çevrimiçi]. Erişim: https://www.oas.org/dsd/publications/Unit/oea79e/oea79e.pdf Erişim Tarihi: 10.12.2019.

[18] W. Saad, A. Taleb, “The Causal Relationship Between Renewable Energy Consumption And Economic Growth: Evidence From Europe," Clean Techn Environ Policy, c. 20, ss. 127-136, 2018.

[19] Engin Özdemir, H. Emre Bağıran, "Güneş Enerjisinden Elektrik Üretiminde Ülkemizde ve AB Ülkelerinde Verilen Teşvikler”, Türkiye 12. Enerji Kongresi, Ankara, Türkiye, 2012.

[20] D. Maradin, L. Cerović, T. Mjeda, "Economic Effects of Renewable Energy Technologies," Naše gospodarstvo/Our Economy, c. 63, s. 2, ss. 49-59, 2017.

[21] R. Sioshansi, "Retail Electricity Tariff And Mechanism Design To Incentivize Distributed Renewable Generation," Energy Policy, c. 95, ss. 498-508, 2016.

[22] H. H. Yıldırım, "Yenilenebilir Enerji Yatırımlarındaki Teşviklerin Yatırım Performansları Üzerine Etkisi”, Finans Ekonomi ve Sosyal Araştırmalar Dergisi, c. 4, s. 3, ss. 330-345, 2019.

[23] W. Strielkowski, E. Volkova, L. Pushkareva, D. Streimikiene, "Innovative Policies For Energy Efficiency And The Use Of Renewables In Households," Energies, c. 12, s. 7, ss. 1392-1409, 2019.

[24] B.J. Kalkbrennera, J. Roosen, "Citizens Willingness To Participate In Local Renewable Energy Projects: The Role Of Community And Trust In Germany," Energy Research \& Social Science, c. 13, ss. 60-70, 2016.

[25] H. Kenneth, B.V. Mathiesen, I.R. Skov, "Full Energy System Transition Towards 100\% Renewable Energy In Germany In 2050," Renewable and Sustainable Energy Reviews, c. 102, ss. 1-13, 2019. 
[26] A. McCabe, D. Pojani, A.B.V. Groenou, "Social Housing And Renewable Energy: Community Energy In A Supporting Role,” Energy Research \& Social Science, c. 38, ss. 110-113, 2018.

[27] J. Curtin, C. McInerney, B.Ó. Gallachóir, "Financial Incentives To Mobilise Local Citizens As Investors In Low-Carbon Technologies: A Systematic Literature Review," Renewable and Sustainable Energy Reviews, c. 75, ss. 534-547, 2017.

[28] R. Hannesson, "How Much Do European Households Pay For Green Energy?," Energy Policy, c. 131 , ss. $235-239,2019$.

[29] J. Horbach, C. Rammer, "Energy Transition In Germany And Regional Spill-Overs: The Diffusion Of Renewable Energy In Firms," Energy Policy, c. 121, ss. 404-414, 2018.

[30] A. Ulusoy, C. Daştan, "Yenilenebilir Enerji Kaynaklarına Yönelik Vergisel Teşviklerin Değerlendirilmesi," Uluslararas1 Emek ve Toplum Dergisi, c. 7, s. 17, ss. 123-160, 2018.

[31] M. Samancı, "Yenilenebilir Enerji Yatırımlarının Arttırılmasına Yönelik Vergisel Teşvikler: Türkiye ve Seçilmiş Bazı Ülkeler Arasında Karşılaştırma," Türkiye Siyaset Bilimi Dergisi, c. 3, s. 1, ss. $55-69,2020$.

[32] Z. Ngadiron, N. H. Radzi, "Feed-In-Tariff And Competitive Auctions As Support Mechanism For Renewable Energy: A Review," ARPN Journal of Engineering and Applied Sciences, c. 11, s. 14, ss. 8938-8946, 2016.

[33] F.Polzin, F. Egli, B. Steffen, T.S. Schmidt, "How Do Policies Mobilize Private Finance For Renewable Energy?-A Systematic Review With An Investor Perspective," Applied Energy, c. 236, ss. 1249-1268, 2019.

[34] S. Abolhosseini, A. Heshmati, "The Main Support Mechanisms to Finance Renewable Energy Development," IZA Discussion Paper, Bonn, Germany, c. 8182, 2014.

[35] S. Şen, "Yenilenebilir Enerji Üretiminde Maliye Politikası Aracı Olarak Teşvikler: Seçilmiş Bazı Avrupa Ülkelerinin Deneyimleri," Journal of Life Economics, c. 11, ss. 59-76, 2017.

[36] K. Neuhoff, N. May, J. Richstein, "Incentives For The Long-Term Integration Of Renewable Energies: A Plea For A Market Value Model, DIW Economic Bulletin," Deutsches Institut für Wirtschaftsforschung (DIW), c. 7, s. 46/47, ss. 467-476, 2017.

[37] E.R. Asensio, D.B. Diez, J. Juan, B. Peiró, A.P. Hoyos, A.C. Santos, "Review Of Wind Energy Technology And Associated Market And Economic Conditions In Spain," Renewable and Sustainable Energy Reviews, c. 101, ss. 415-427, 2019.

[38] K. Lancker, M.F. Quaas, "Increasing Marginal Costs And The Efficiency Of Differentiated Feed-In Tariffs,” Energy Economics, c. 83, ss. 104-118, 2019.

[39] A. Ülgen, "Yenilenebilir Enerji Kullanımını Teşvik Yolları Üzerine Bir Değerlendirme," Yüksek Lisans Tezi, Temiz Tükenmez Enerjiler Anabilim Dal, Hacettepe Üniv., Ankara, 2018.

[40] Danish Energy Agency, "Energistatistik 2018," [Çevrimiçi]. Erişim: https://ens.dk/sites/ens.dk/files/Analyser/energistatistik_2018.pdf Erişim Tarihi: 14.12.2019.

[41] J. Curtin, C. McInerney, L. Johannsdottir, "How Can Financial Incentives Promote Local Ownership Of Onshore Wind And Solar Projects? Case Study Evidence From Germany, Denmark, The UK And Ontario," Local Economy, c. 33, s. 1, ss. 40-62, 2017. 
[42] Danish Energy Agency, "Danish Energy Model," [Çevrimiçi]. Erişim: https://ens.dk/en/ourresponsibilities/global-cooperation/danish-energy-model Erişim Tarihi: 15.12.2019.

[43] Danish Energy Agency, "Energy and Climate Politics," [Çevrimiçi]. Erişim: https://ens.dk/en/our-responsibilities/energy-climate-politics Erişim Tarihi: 14.12.2019.

[44] Avrupa Birliği Komisyonu, "State aid: Commission approves $€ 550$ million Danish scheme to support electricity production from biomass installations", [Çevrimiçi]. Erişim: https://ec.europa.eu/info/news/state-aid-commission-approves-eu550-million-danish-scheme-supportelectricity-production-biomass-installations-2020-may-19_en Erişim Tarihi: 06.12.2020

[45] K. Wikberg, "Promotion in Denmark," Legal Sources On Renewable Energy, 1 Haziran, 2019. [Çevrimiçi]. Erişim: http://www.res-legal.eu/search-by-country/denmark/single/s/rese/t/promotion/aid/premium-tariff-law-on-the-promotion-of-renewable-energy/lastp/96

[46] J. Curtin, C. Mclnerney, L. Johannsdottir, "How can financial incentives promote local ownership of onshore wind and solar projects? Case study evidence from Germany, Denmark, the UK and Ontario," Local Economy, c. 33, s. 1, ss.40-61, 2018.

[47] UK Goverment, Digest of UK Energy Statistics-Dukes, (30 Temmuz, 2020). [Çevrimiçi]. Erişim https://www.gov.uk/government/statistics/electricity-chapter-5-digest-of-united-kingdom-energystatistics-dukes

[48] Ofgem, "Feed-In Tariff (FIT) Rates," [Çevrimiçi]. Erişim: https://www.ofgem.gov.uk/environmental-programmes/fit/fit-tariff-rates Erişim Tarihi: 22.01.2020.

[49] Energypedia, "Renewable Energy Quota and Certificate Schemes," [Çevrimiçi]. Erişim: https://energypedia.info/wiki/Renewable_Energy_Quota_and_Certificate_Schemes Erişim Tarihi: 09.12.2019.

[50] UK Goverment, Feed-In Tariffs: Get Money For Generating Your Own Electricity," 3 Şubat, 2020. Erişim: https://www.gov.uk/feed-in-tariffs

[51] W. Eadson, M. Foden, "State, Community And The Negotiated Construction Of Energy Markets: Community Energy Policy In England," Geoforum, c. 100, ss. 21-31, ISSN 0016-7185, 2019.

[52] UK Goverment, Feed-In Tariffs, 29 Temmuz, 2020. Erişim: https://www.fitariffs.co.uk/

[53] G. Maroulis, Renewable energy policy database and support, Legal Sources On Renewable Energy. 09 Ocak, 2020. [Çevrimiçi]. Erişim: http://www.res-legal.eu/search-by-country/unitedkingdom/tools-list/c/united-kingdom/s/res-e/t/promotion/sum/204/lpid/203

[54] Energy Charts, "Net public electricity generation in Germany in 2018," [Çevrimiçi]. Erişim: https://www.energy-charts.de/energy_pie.htm?year=2018 Erişim Tarihi: 15.12.2019.

[55] K. Hansen, B.V. Mathiesen, I.R. Skov, "Full energy system transition towards 100\% Renewable energy in Germany in 2050," Renewable and Sustainable Energy Reviews, c. 102, ss. 1-13, 2019.

[56] BMW, "Energiedaten: Gesamtausgabe, Bundesministerium Für Wirtschaft Und Energie," Germany, 2012, [Çevrimiçi] ]Erişim: https://www.bmwi.de/Redaktion/DE/Downloads/Energiedaten/energiedaten-gesamt-pdfgrafiken.pdf?blob=publicationFile \&v=40 
[57] T. Sternkopf, "Germany Support schemes," Legal Sources On Renewable Energy, [Çevrimiçi]. Erişim: http://www.res-legal.eu/search-by-country/germany/summary/c/germany/s/res-e/sum/136/lpid/ 135 Erişim Tarihi: 15.12.2019.

[58] Y. Bayraktar, H. İ. Kaya, "Yenilenebilir Enerji Politikaları ve Rüzgâr Enerjisi Açısından Bir Karşılaştırma: Çin, Almanya ve Türkiye Örneği”, Uluslararası Ekonomik Araştırmalar Dergisi, c. 2. S. 4, ss. 1-18, 2016.

[59] T.C. Enerji ve Tabii Kaynaklar Bakanlığı, "Elektrik", [Çevrimiçi]. Erişim: https://enerji.gov.tr/bilgi-merkezi-enerji-elektrik Erişim Tarihi: 01.12.2019.

[60] 5346 Sayılı Enerji Kaynaklarının ve Enerjinin Kullanımında Verimliliğin Artırılmasına Dair Yönetmelik, Resmî Gazete, Sayı: 25819, 18 Mayıs 2005.

[61] T.C. Bakanlar Kurulu, (2013, Kasım 18), "5625 Sayılı Bakanlar Kurulu Kararı”, [Çevrimiçi]. Erişim: https://www.resmigazete.gov.tr/eskiler/2013/12/20131205-8.htm Erişim Tarihi: 06.12.2020.

[62] Yenilenebilir Enerji Kaynaklarından Elektrik Enerjisi Üreten Tesislerde Kullanılan Yerli Aksamın Desteklenmesi Hakkında Yönetmelik, Resmî Gazete, Sayı: 29752, 24 Haziran 2016.

[63] 6446 Sayılı Elektrik Piyasası Kanunu, Resmî Gazete, Sayı: 28603, 30 Mart 2013.

[64] T.C. Bakanlar Kurulu, (2012 Haziran 12), "3305 Sayılı Yatırımlarda Devlet Yardımı Hakkında Bakanlar Kurulu Kararı", [Çevrimiçi]. Erişim: https://www.resmigazete.gov.tr/eskiler/ 2012/06/20120619-1.htm Erişim Tarihi: 06.12.2020

[65] T.C. Sanayi ve Teknoloji Bakanlığı, (2020 Ağustos), "Yatırım Teşvik Uygulamaları Sunumu", [Çevrimiçi]. Erişim: https://www.sanayi.gov.tr/destek-ve-tesvikler/yatirim-tesvik-sistemleri /md0103011615 Erişim Tarihi: 06.12.2020

[66] T.C. Kalkınma Bakanlığı, (2018), "11. Kalkınma Planı Enerji Üretiminde Yerli Üretim Çalışma Grubu Raporu”, [Çevrimiçi], Erişim https://sbb.gov.tr/wp-content/uploads/2020/04/ EnerjiTeknolojilerindeYerliUretimCalismaGrubuRaporu.pdf] Erişim Tarihi: 06.12.2020

[67] O. Yılmaz, H. Hortunluoğlu, "Yenilenebilir Enerjiye Yönelik Teşvikler ve Türkiye”, Adnan Menderes Üniversitesi Sosyal Bilimler Enstitüsü Dergisi, c. 2, s. 2, ss. 74-97, 2015.

[68] T. Sternkopf, "Turkey: Summary of support schemes," Legal Sources On Renewable Energy, [Çevrimiçi]. Erişim: http://www.res-legal.eu/search-by-country/turkey/single/s/rese/t/promotion/aid/feed-in-tariff-7/lastp/207/ Erişim Tarihi: 15.12.2019.

[69] M. Ertürk, "The Evaluation Of Feed-In Tariff Regulation Of Turkey For Onshore Wind Energy Based On The Economic Analysis," Energy Policy, c. 45, ss. 359-367, 2012.

[70] O. Lecuyer, P. Quirion, "Interaction Between CO2 Emissions Trading And Renewable Energy Subsidies Under Uncertainty: Feed-In Tariffs As A Safety Net Against Over-Allocation," Climate Policy, c. 19, s. 8, ss. 1002-1018, 2018.

[71] TEİAŞ, (2019), “Türkiye'nin Yenilenebilir Kaynaklarına Ait Kurulu Gücünün Toplam Kurulu Güç İçindeki Payının Yıllar İtibariyle Gelişimi”, [Çevrimiçi] Erişim: https://webapi.teias.gov.tr/file/6ec2f3a6-6c02-4da8-ac5c-6659ae2f3ce2?download Erişim Tarihi: 06.12.2020. 